\title{
Seismic Isolation of Building-Equipment System Using Modified Variable Friction Pendulum System
}

\author{
Darshak Patel ${ }^{1}$, V. R. Panchal' ${ }^{2}$, Maulik Patel ${ }^{3}$ \\ ${ }^{1,2}$ Chandubhai S. Patel Institute of Technology, Charotar University of Science and Technology, Changa, \\ Gujarat, India. \\ ${ }^{3}$ Knowledge Institute of Technology and Engineering, Bakrol, Gujarat, India. \\ 1Email: darshak254@gmail.com
}

ARTICLE INFORMATION

DOI: $10.15415 /$ jotitt.2019.71003

Keywords: Base isolation, MVFPS, Building- equipment, Near-fault ground excitation

\begin{abstract}
In this study, building-equipment system with Modified Variable Friction Pendulum System (MVFPS) is investigated under different earthquake ground excitations. Earthquake response of buildingequipment system isolated with MVFPS is compared with Variable Friction Pendulum System (VFPS) and Friction Pendulum System (FPS) in order to find efficiency of MVFPS. Newmark's linear acceleration method is used for solving governing equation of motion for building-equipment system. In this investigation, different storey buildings are considered. It is observed that MVFPS is more efficient in reducing the recoverable energy than FPS, but less efficient than VFPS. From the comparative study, it is found that FPS shows robust performance in comparison to MVFPS and VFPS in reducing equipment acceleration and displacement.
\end{abstract}

\section{Introduction}

In last few decades, base isolation technique has gained vast adoption because it protects different types of structures, like water tanks, multistoreyed buildings, bridges etc. against adverse effects of earthquake. The main concept of base isolation technique is that it reduces damages in building by shifting the fundamental time period of building from dominant periods of earthquake. After implementation of base isolation system in building, energy dissipation capability and fundamental time period of building increases. Buildings without base isolation attract more earthquake forces where as buildings which have base isolation attract less amount of earthquake force and protect building against earthquake.

Among different types of base isolation systems, sliding isolators are mostly used for actual implementation as they are insensitive to the frequency content of ground motions. Number of sliding isolators, i.e., Friction pendulum system (FPS), Variable Frequency Pendulum Isolator (VFPI), Variable Curvature Friction Pendulum System (VCFPS), and Triple Friction Pendulum System (TFPS) were examined during last few decades. Mrunal and Sinha [1] supervised study on multi-storey building along with equipment 
with VFPI, PF and FPS; they concluded that VFPI is more effective as compared to FPS and PF system. Lu et al. [2] considered sliding bearings with variable curvatures for near fault ground motions. They showed that CFPI and VFPI is more effective compared to FPS. Joshi et al. [3] studied performance of CFPI and VFPI in multi-storey building with building equipment and concluded that VFPI is more effective than CFPI. Bhayani and Panchal [4] carried out numerical study on multi-storey building with equipment isolated with PFPI and VFPI and demonstrated that VFPI is more effective than PFPI.

In this research work, MVFPS isolated multi-storey building with equal mass at all floor are considered. Here Equipment mass is taken $1 \%$ of total mass of building. Different near fault ground excitations are used to determine response of equipment displacement, equipment accelerations and recoverable energy of MVFPS isolated building with view to examine the performance of MVFPS with building equipment. Comparison of MVFPS, VFPS and FPS has been made.

\section{Concept of MVFPS}

As variation of coefficient of friction is not easy to be attain in case of VFPS, Ali and Abbas [5] suggested MVFPS, which is more advantageous in real practice. The MVFPS system is the variation of VFPS system. The basic difference among FPS, VFPS and MVFPS lies in the variation of friction coefficient with respect to isolator displacement, which is demonstrated in Fig. 1. Variation of friction coefficient in case of MVFPS is similar to that of FPS throughout isolator except in displacement range from $0.5 d$ to $1.5 d$ ( $d$ is the value of isolator displacement with respect to extreme value of friction coefficient of VFPS). In this range, maximum value of friction coefficient of VFPS is considered.

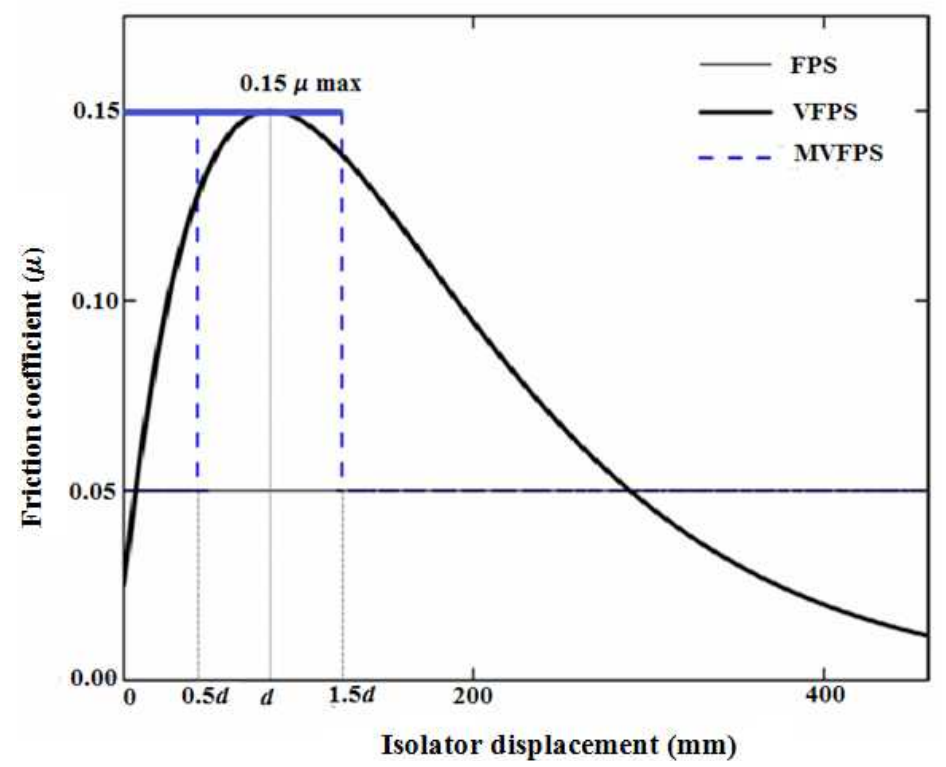

Figure 1: Friction coefficient variation of FPS, VFPS and MVFPS [6] 


\section{Governing equation of motion}

The governing equation of motion for building equipment system is given by Eq. (1).

$[M]\{\ddot{x}\}+[C]\{\dot{x}\}+[K]\{x]=-[M]\{r\}\left\{\ddot{x}_{b}+\ddot{x}_{g}\right\}$

Here, $[M],[C]$ and $[K]$ represents mass, damping and stiffness matrices having size of $N$ X $N ;\{r\}$ stands for influence coefficient vector and its value is $\{1,1, \ldots$, $1\}^{T} ;\{\ddot{x}\}$ and $\{\dot{x}\}$ denotes acceleration and velocity vector, respectively, $\{x\}$ denotes displacement with respect to base mass, $\ddot{x}_{g}$ indicates earthquake ground acceleration, while $\ddot{x}_{b}$ denotes base mass acceleration with respect to the ground. The equation of restoring force of MVFPS is given by Eq. (2).

$$
F_{b}=k_{b} x_{b}+F_{x}
$$

where $F_{\mathrm{x}}$ denotes frictional force in MVFPS, $k_{b}=W / R$ represents stiffness of MVFPS; $R$ indicates radius of concave interface of MVFPS.

The MVFPS can be subjected (before sliding) to the limiting frictional force, $Q$ which is given by Eq. (3).

$Q=\mu W$

where $\mu$ and $W$ indicate coefficient friction of MVFPS and weight of structure. Stiffness $k_{b}$, of MVFPS is designed in such a way that certain value of isolation period, $T_{b}$, is obtained; which is given by Eq. (4).

$T_{b}=2 \pi \sqrt{\frac{M}{k_{b}}}$

In above equation $M$ indicate total mass of the MVFPS-isolated building with equipment. The MVFPS has nonlinear force deformation behaviour. So, it becomes very tough to solve the equations of governing motion of the building equipment system by classical modal superposition technique. Therefore, the
Newmark's linear acceleration method is used to obtain solution of this equation over small time step.

\section{Energy balance}

Base isolators work as a combination of reducing the energy transferred to the structure and dissipating energy by applicable mechanism. Most of the time it becomes difficult to select convenient trade off among isolator displacements and structural deformations in order to obtain best isolator properties. With the help of energy quantities, it becomes easier to evaluate the isolator performance as it involves all the responsible quantities. Hence, it represents overall response of structure. The equation of energy balance stated by Uang and Bertero [6] for base isolated shown in Eq. (5).

$$
\begin{aligned}
& \frac{1}{2} \dot{x}_{0_{t}}^{T} M_{0} \dot{x}_{0 t}+\frac{1}{2} m_{b} \dot{x}_{h}^{2}+m_{t} g y+\frac{1}{2} x_{0}^{T} K_{0} x_{0}+ \\
& \int\left[\dot{x}_{0}^{T} C_{0} \dot{x}_{0}\right] d t+\int m_{t} \mu g \operatorname{sgn}\left(\dot{x}_{b}\right) d x_{b}=\int\left[\dot{x}_{0}^{T} M_{0} r_{0}\right] d x_{g} \\
& +\int m_{b} x_{b_{h}} d x_{g}
\end{aligned}
$$

where subscript ' $t$ ' indicates absolute values of response quantities. Simplified form of Eq. (5) is given by Eq. (6).

$V_{k}+V_{r}+V_{s}+V_{\xi}+V_{\mu}=V_{i}$

In above equation, terms $V_{K}, V_{r} V_{s}$ and $V i$ stand for to the kinetic energy, potential energy, strain energy and absolute input energy respectively. $\boldsymbol{V}_{\boldsymbol{\xi}}$ and $\boldsymbol{V}_{\boldsymbol{\mu}}$ indicate the non conservative energies because of structural damping and sliding friction.

The energy balance equation of a equipment resting on the MVFPS isolated building at any instant of time is given by Eq. (7).

$$
V_{k}+V_{r}=V_{i}
$$

Equation of $V_{k}$ and $V_{r}$ are given by (8) and (9) 
$V_{k}=1 / 2 \times$ (mass of the equipment) $\mathrm{X}$ (absolute velocity of the equipment $)^{2}$

$V_{k}=1 / 2 \times$ (stiffness of the equipment)

(relative displacement of the equipment with respect to top floor $)^{2}$

\section{Numerical study}

In this study, MVFPS isolated one and five storey buildings with equal mass are considered. Also, light equipment with $1 \%$ of total floor mass of building is considered at top. In this study, the response of building equipment system is carried out under six different near-fault ground excitations. Fig. 2 \& 3 show one \& five storey buildings with equipment at top isolated with MVFPS. Table 1 \& 2 indicate characteristics of near-fault ground motion and properties of building \& equipment.

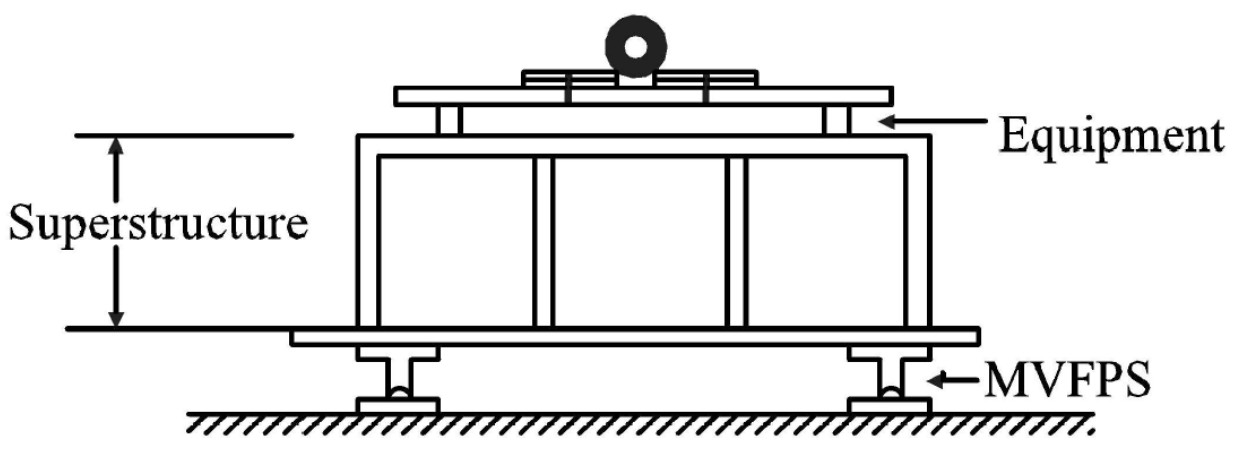

Figure 2: One storey building with equipment isolated using MVFPS

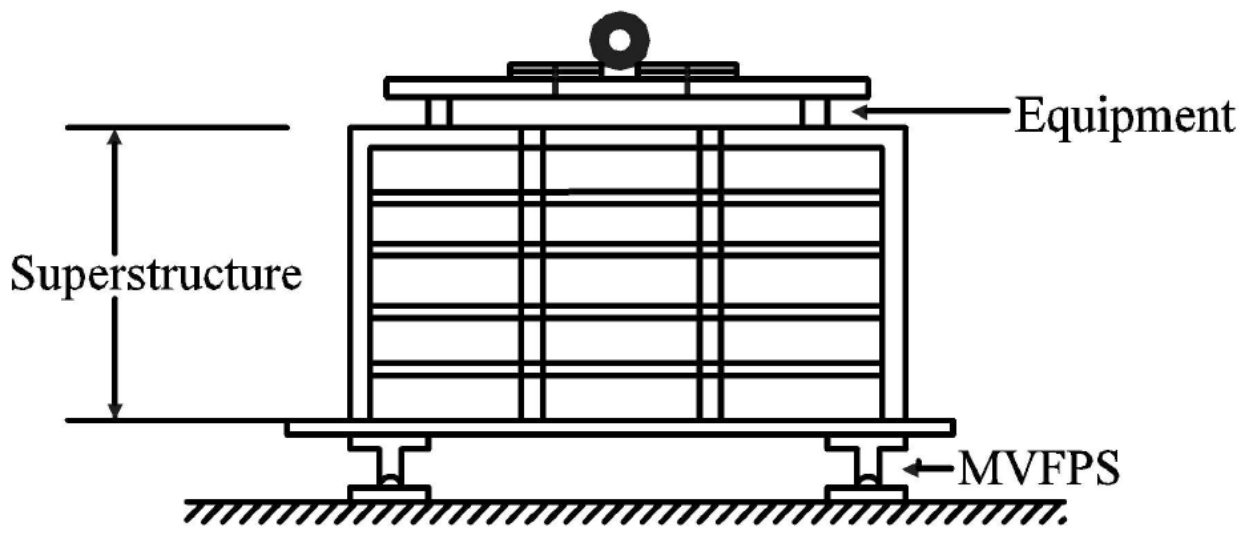

Figure 3: Five storey building with equipment isolated using MVFPS 
Table 1: Characteristics of considered six earthquakes

\begin{tabular}{|l|c|c|c|}
\hline \multicolumn{1}{|c|}{ Near-fault Ground excitation } & $\begin{array}{c}\text { PGD } \\
(\mathbf{c m})\end{array}$ & $\begin{array}{c}\text { PGV } \\
(\mathbf{c m} / \mathbf{s})\end{array}$ & $\begin{array}{c}\text { PGA } \\
(\mathbf{g})\end{array}$ \\
\hline 1979, Imperial Valley (El Centro Array \#5) & 76.5 & 98 & 0.37 \\
\hline 1979, Imperial Valley (E 1 Centro Array \#7) & 49.1 & 113 & 0.46 \\
\hline 1994, Northridge (Newhall) & 38.1 & 119 & 0.72 \\
\hline 1992, Landers (Lucerne Valley) & 230 & 136 & 0.71 \\
\hline 1994, Northridge (Rinaldi) & 39.1 & 175 & 0.89 \\
\hline 1994, Northridge (Sylmar) & 31.1 & 122 & 0.73 \\
\hline
\end{tabular}

Table 2: Building and equipment properties

\begin{tabular}{|c|c|}
\hline Mass of each floor & $60080 \mathrm{~kg}$ \\
\hline Storey stiffness for each floor & $11260 \mathrm{kN} / \mathrm{m}$ \\
\hline Equipment mass & $1 \%$ of floor mass \\
\hline Damping ratio of building & $5 \%$ \\
\hline Damping ratio of equipment & $5 \%$ \\
\hline Equipment -frequency & $3.85 \mathrm{~Hz}$ \\
\hline Ratio of base mass to floor mass & 1.0 \\
\hline
\end{tabular}

\section{Results and discussion}

Fig. 4 to 6 depict time variation of equipment acceleration, equipment displacement and recoverable energy of building - equipment system of one storey building isolated using MVFPS, VFPS and FPS under near-fault ground motions and Fig. 8 to 10 depict time variation of equipment acceleration, equipment displacement and recoverable energy of building-equipment system of five storey building isolated using MVFPS, VFPS and FPS under near field ground motions.

Fig. 7 and 11 demonstrate the hysteresis loops of MVFPS, VFPS and FPS for various near-fault ground motions for one and five storey buildings with equipment.

Table $3 \& 4$ shows comparison results of peak response quantities and isolator displacement and base shear under different earthquake ground excitations.

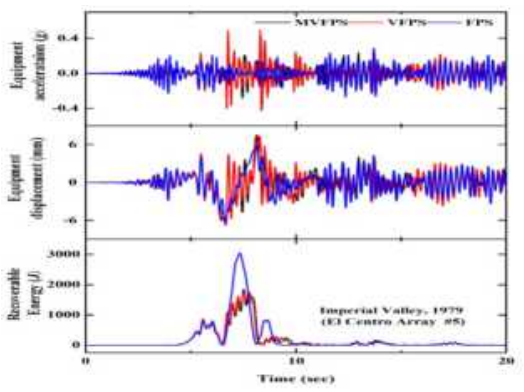

(a) 


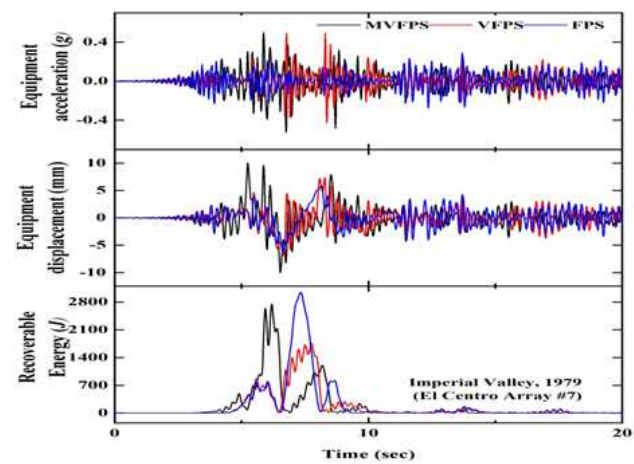

(b)

Figure 4: (a) and (b) Shows time vs. equipment acceleration, equipment displacement and recoverable energy of single storey building-equipment isolated with MVFPS, VFPS and FPS under Imperial Valley (El Centro Array \#5) and Imperial Valley (El Centro Arra\#7)

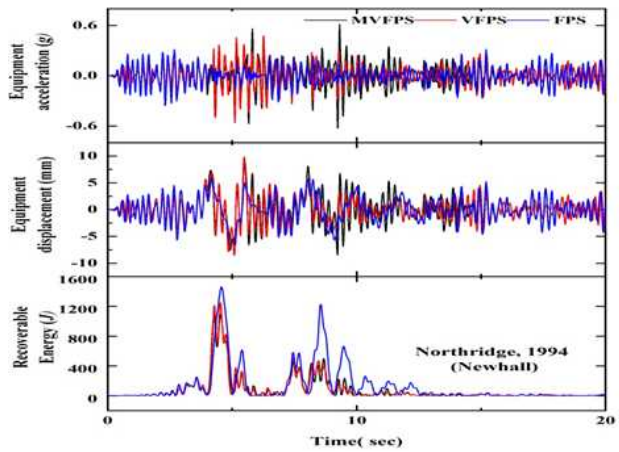

(a)

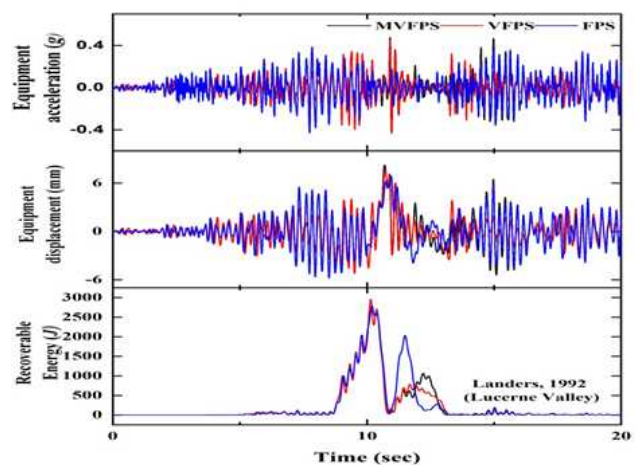

(b)

Figure 5: (a) and (b) Shows time vs. equipment acceleration, equipment displacement and recoverable energy of single storey building-equipment isolated with MVFPS, VFPS and FPS under Northridge, 1994 (Newhall) and Landers, 1992 (Lucerne Valley) 


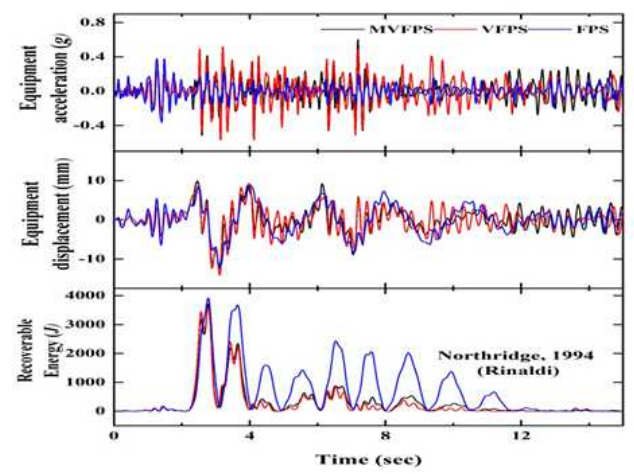

(a)

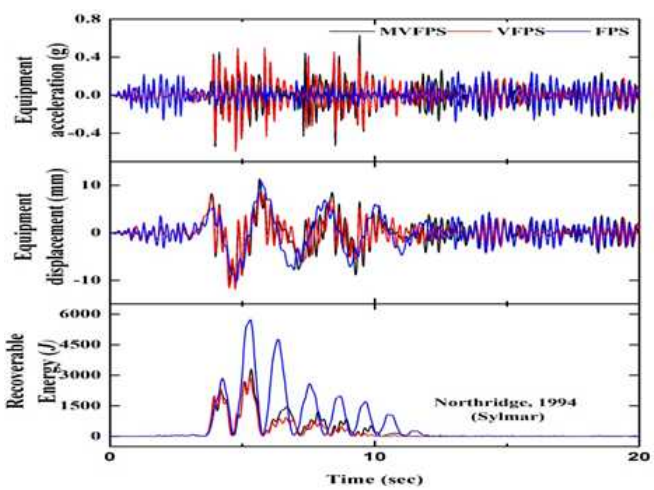

(b)

Figure 6: (a) and (b) Shows time vs. equipment acceleration, equipment displacement and recoverable energy of single storey building-equipment isolated with MVFPS, VFPS and FPS under Northridge, 1994 (Rinaldi) and Northridge, 1994 (Sylmar)

Here in above figures, Fig 4 (a) \& (b) shows Time vs. equipment acceleration, displacement and recoverable energy of single storey building-equipment isolated with MVFPS, VFPS and FPS under Imperial valley (El Centro Array \#5) in this earthquake ground excitations FPS is good compared to MVFPS and VFPS reducing equipment acceleration and equipment displacement But in case of recoverable energy VFPS show better performance compared to MVFPS and VFPS and in Imperial valley (El Centro Array\#7) FPS is better in both equipment acceleration and equipment displacement compared to
MVFPS and VFPS and in MVFPS recoverable energy is less compared to VFPS and FPS.

In Fig 5 (a) Northridge, 1994 (Newhall) in this earthquake ground excitations equipment acceleration and equipment displacement found less compared to MVFPS and VFPS and MVFPS is better compared to VFPS and FPS in reducing recoverable energy and Fig 5 (b) Landers 1992 (Lucerne Valley) shows that FPS show better in reducing equipment acceleration and equipment displacement and in MVFPS recoverable energy is less compared to VFPS and FPS. 
In Fig 6 (a) Northridge 1994 (Rinaldi) in this earthquake ground excitations equipment acceleration and equipment displacement is less in FPS compared to MVFPS and VFPS and recoverable energy is less in VFPS and Fig 6 (b) shows that in Northridge 1994 (Sylmar)

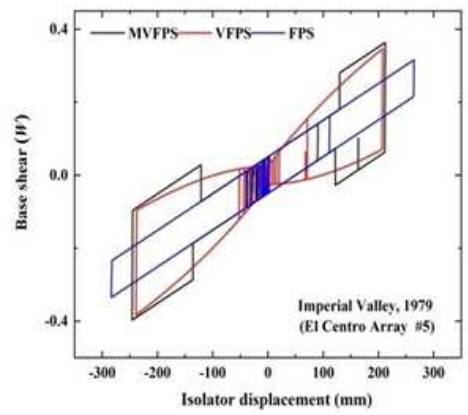

(a)

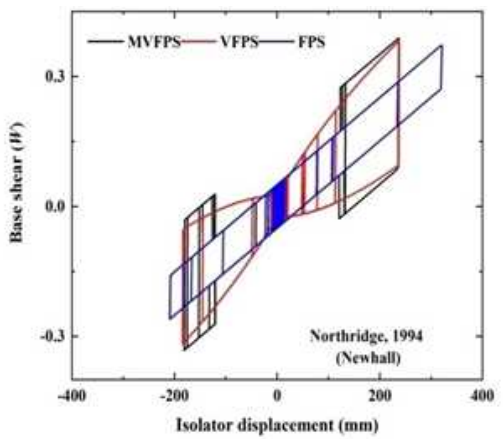

(c)

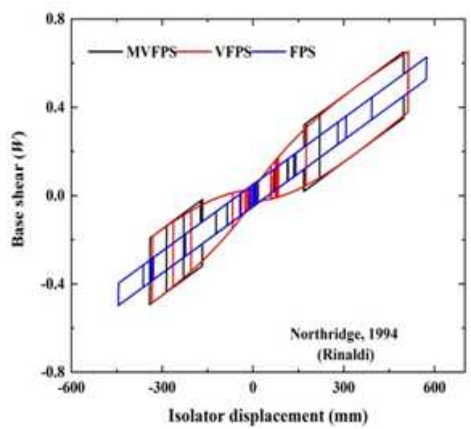

(e) earthquake ground excitations FPS shows robust performance compared to MVFPS and VFPS and also it founds that recoverable energy is very less in VFPS.

All the results value of Fig 4 to 6 shows in Table 3.

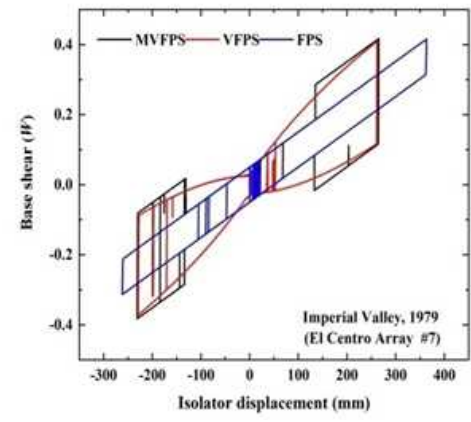

(b)

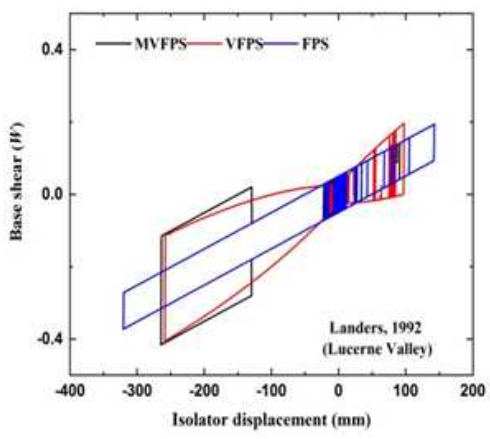

(d)

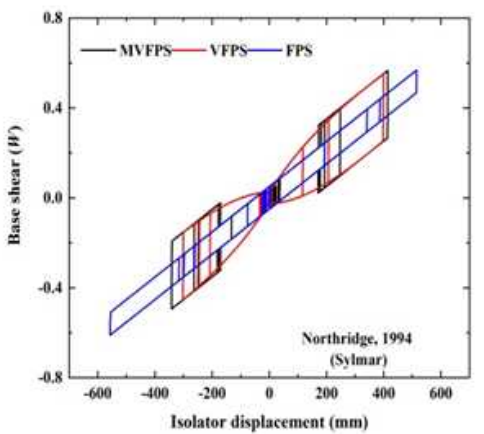

(f)

Figure 7: (a to f) Shows hysteresis loop of MVFPS, VFPS and FPS for single storey building with equipment under different earthquake ground excitations

ISSN No.: 232 1-3906 (Print) ISSN No.: 2321-7146 (Online) Registration No.: CHAENG/2013/51235 Periodicity: Bi-Annually 


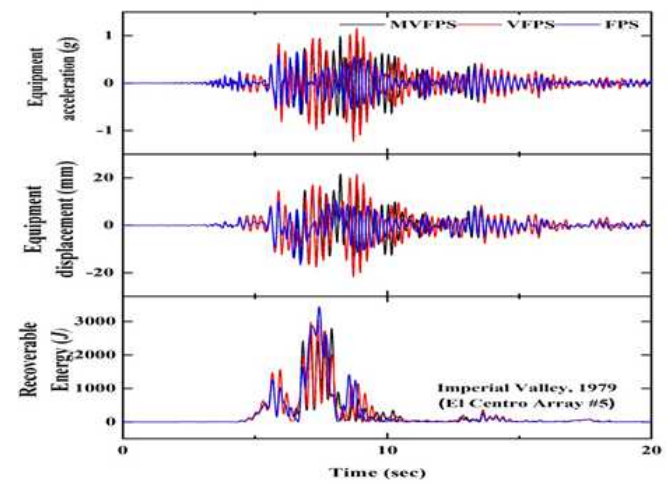

(a)

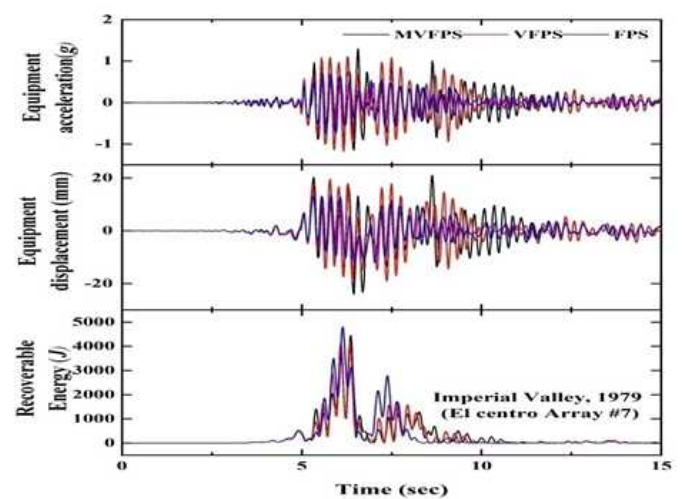

(b)

Figure 8: (a) and (b) Shows time vs. equipment acceleration, equipment displacement and recoverable energy of five storey building-equipment isolated with MVFPS, VFPS and FPS under different earthquake ground excitations

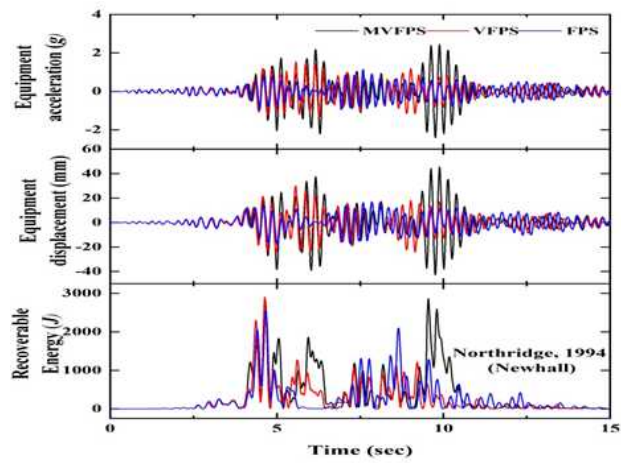

(a)

ISSN No.: 232 1-3906 (Print) ISSN No.: 2321-7146 (Online) Registration No.: CHAENG/2013/51235 Periodicity: Bi-Annually 


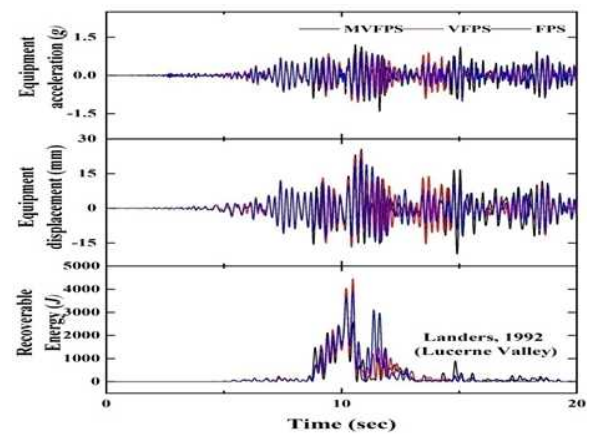

(b)

Figure 9: (a) and (b) Shows time vs. equipment acceleration, equipment displacement and recoverable energy of five storey building-equipment isolated with MVFPS, VFPS and FPS under different earthquake ground excitations

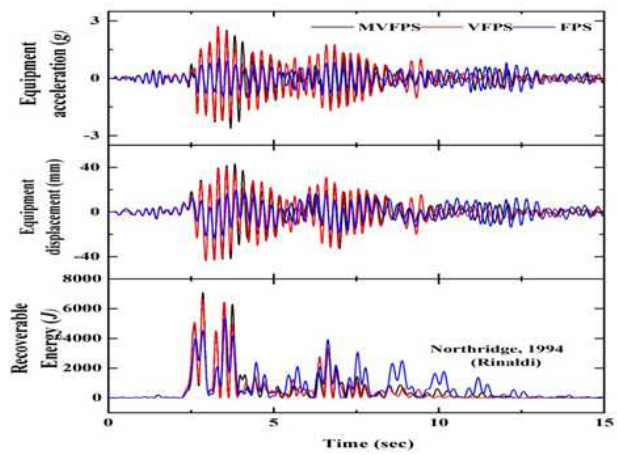

(a)

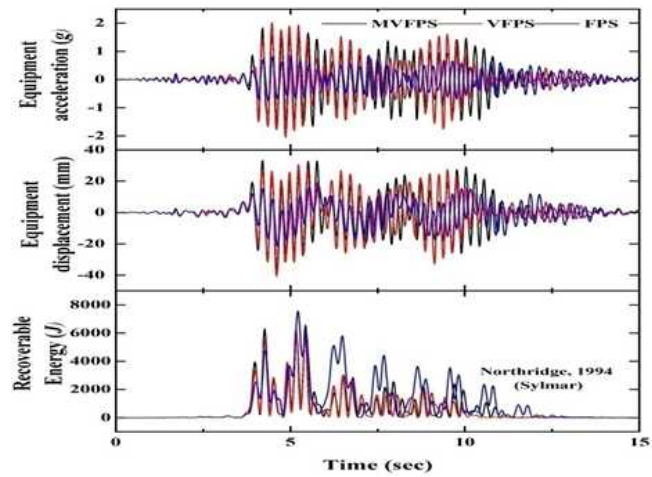

(b)

Figure 10: (a) and (b) Shows time vs. equipment acceleration, equipment displacement and recoverable energy of five storey building-equipment isolated with MVFPS, VFPS and FPS under different earthquake ground excitations 
From above Figures, Fig. 8 (a) Imperial valley (El Centro Array\#5) earthquake ground excitations shows that for five storey building-equipment system equipment acceleration and equipment displacement is less in FPS compared to MVFPS and VFPS and also recoverable energy result less in MVFPS and in Fig 8. (b) Imperial valley (El Centro Array\#7) in this earthquake ground excitations FPS is good compared to MVFPS and VFPS. and recoverable energy found less in VFPS,

Both Fig. 9 (a) Northridge 1994 (Newhall) (b) Landers 1992 (Lucerne Valley) shows that equipment acceleration, displacement and recoverable energy is less in FPS compared to MVFPS

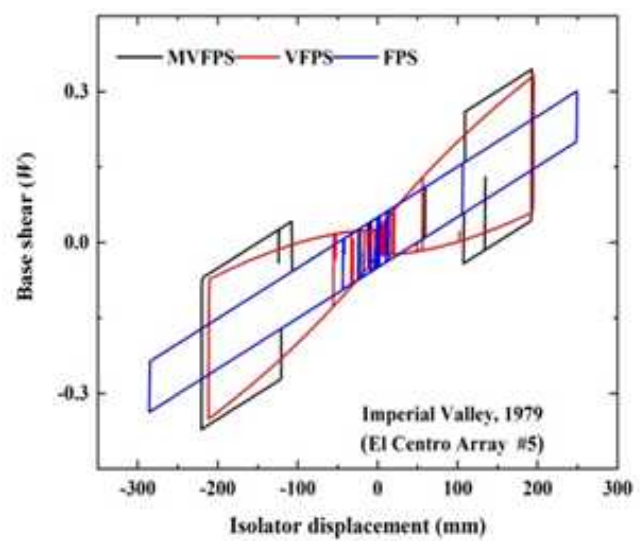

(a)

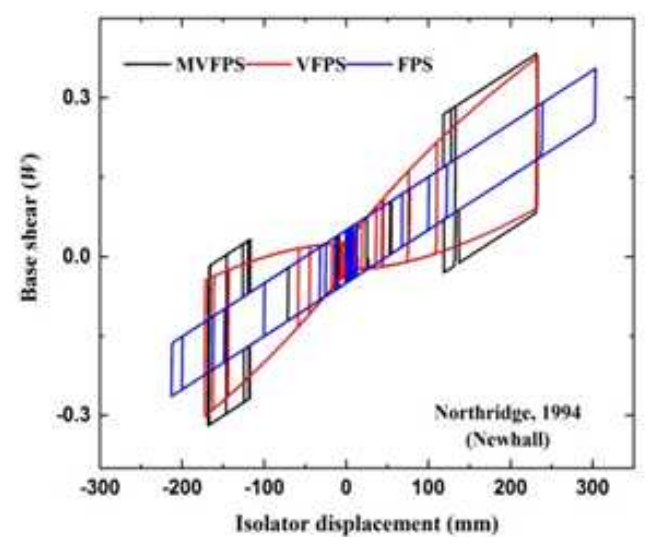

(c) and VFPS.

Fig. 10 (a) Northridge 1994 (Rinaldi) in this earthquake excitations equipment acceleration, displacement and recoverable energy is less in FPS compared to MVFPS and VFPS and 10 (b) shows that in Northridge 1994 (Sylmar) earthquake excitations equipment acceleration placement is high in VFPS but recoverable energy value is less in VFPS compared to MVFPS and FPS.

Result values of Fig. 8 to 10 Which depict Time vs equipment acceleration, displacement and recoverable energy of five storey building-equipment isolated with MVFPS,VFPS and FPS under different earthquake ground excitations shows in Table 3.

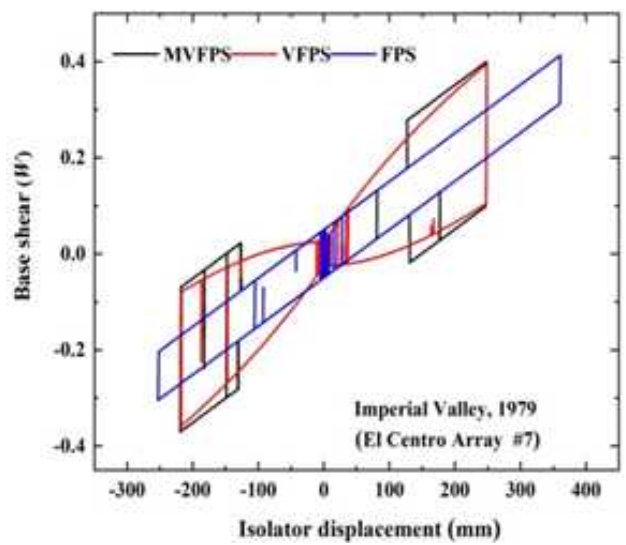

(b)

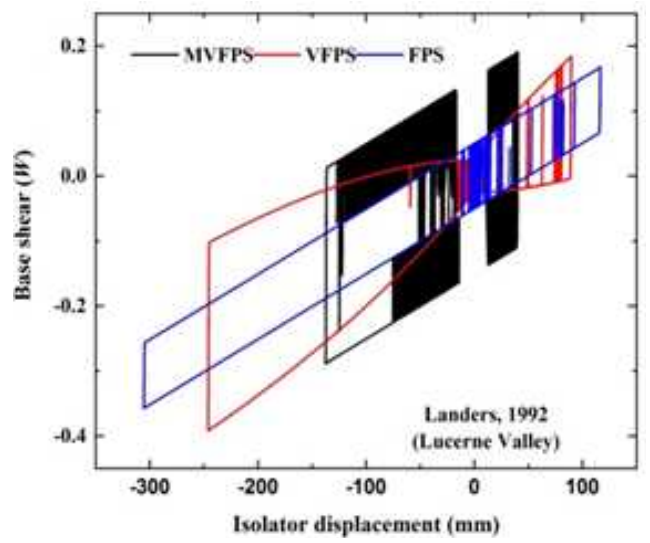

(d) 


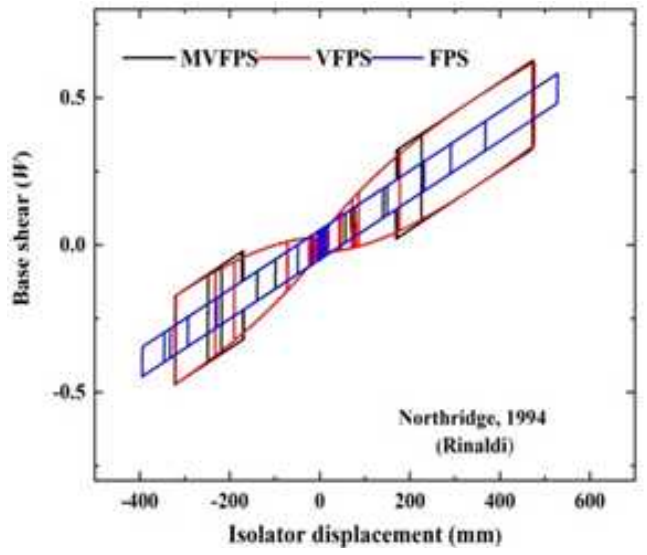

(e)

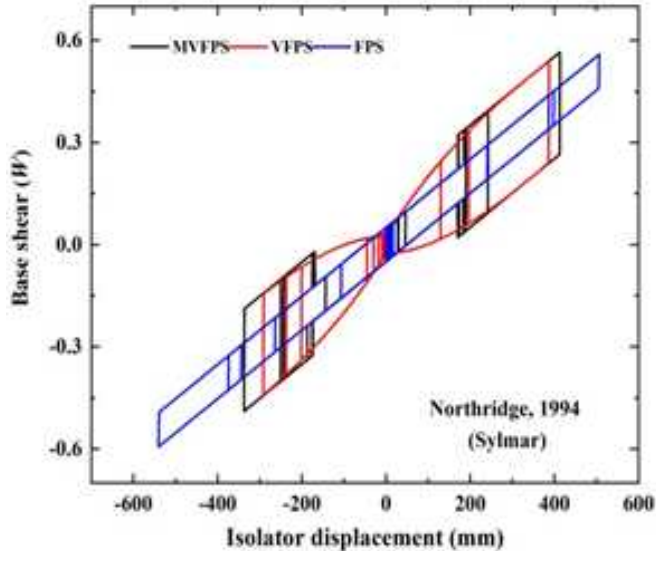

(f)

Figure 11: (a to f) shows Hysteresis loop of MVFPS, VFPS and FPS for five storey building with equipment under different earthquake ground excitations

Table 3: Comparison of peak response quantities under different earthquake ground excitations

\begin{tabular}{|c|c|c|c|c|c|c|c|}
\hline \multirow[b]{2}{*}{$\begin{array}{l}\text { Earthquake } \\
\text { ground motion }\end{array}$} & \multirow[b]{2}{*}{ Isolator } & \multicolumn{3}{|c|}{$N=1$} & \multicolumn{3}{|c|}{$N=5$} \\
\hline & & $\begin{array}{l}\text { Equipment } \\
\text { Accelera- } \\
\text { tion } \\
(\mathrm{g})\end{array}$ & $\begin{array}{c}\text { Equipment } \\
\text { Displace- } \\
\text { ment } \\
(\mathrm{mm})\end{array}$ & $\begin{array}{l}\text { Recover- } \\
\text { able } \\
\text { Energy } \\
(\mathrm{J})\end{array}$ & $\begin{array}{l}\text { Equipment } \\
\text { Accelera- } \\
\text { tion } \\
(\mathrm{g})\end{array}$ & $\begin{array}{c}\text { Equipment } \\
\text { Displace- } \\
\text { ment } \\
(\mathrm{mm})\end{array}$ & $\begin{array}{c}\text { Recoverable } \\
\text { Energy } \\
(\mathrm{J})\end{array}$ \\
\hline \multirow{3}{*}{$\begin{array}{c}\text { Imperial } \\
\text { Valley,1979 } \\
\text { El Centro } \\
\text { (Array \#5) }\end{array}$} & MVFPS & 0.48 & 7.531 & 1846 & 0.988 & 21.527 & 2794 \\
\hline & VFPS & 0.49 & 7.342 & 1766 & 1.151 & 21.719 & 3068 \\
\hline & FPS & 0.29 & 6.315 & 3047 & 0.6614 & 16.656 & 3439 \\
\hline \multirow{3}{*}{$\begin{array}{c}\text { Imperial } \\
\text { Valley,1979 } \\
\text { El Centro } \\
\text { (Array \#7) }\end{array}$} & MVFPS & 0.52 & 10.04 & 2749 & 1.1353 & 22.484 & 4496 \\
\hline & VFPS & 0.57 & 10.51 & 2966 & 1.176 & 19.536 & 4167 \\
\hline & FPS & 0.28 & 7.70 & 3277 & 0.7621 & 13.514 & 4792 \\
\hline \multirow{3}{*}{$\begin{array}{c}\text { Northridge } \\
1994 \\
\text { (Newhall) }\end{array}$} & MVFPS & 0.63 & 8.68 & 1118 & 2.445 & 45.56 & 2863 \\
\hline & VFPS & 0.56 & 9.85 & 1250 & 1.5456 & 29.993 & 2905 \\
\hline & FPS & 0.36 & 6.645 & 1463 & 1.148 & 18.116 & 2544 \\
\hline \multirow{3}{*}{$\begin{array}{c}\text { Landers } \\
1992 \\
\text { (Lucerne Valley) }\end{array}$} & MVFPS & 0.48 & 8.23 & 2798.1 & 1.417 & 25.58 & 3946 \\
\hline & VFPS & 0.46 & 7.59 & 2957 & 1.0616 & 24.717 & 4451 \\
\hline & FPS & 0.43 & 6.87 & 2798.3 & 1.0184 & 21.697 & 3939 \\
\hline \multirow{3}{*}{$\begin{array}{c}\text { Northridge } \\
1994 \\
\text { (Rinaldi) }\end{array}$} & MVFPS & 0.6 & 12.5 & 3710 & 2.7115 & 43.717 & 7068 \\
\hline & VFPS & 0.57 & 14.1 & 3590 & 2.7823 & 43.584 & 6629 \\
\hline & FPS & 0.38 & 12.1 & 3917 & 1.1105 & 23.326 & 5049 \\
\hline \multirow{3}{*}{$\begin{array}{c}\text { Northridge } \\
1994 \\
\text { (Sylmar) }\end{array}$} & MVFPS & 0.63 & 11.3 & 3301 & 1.8339 & 38.027 & 6563 \\
\hline & VFPS & 0.59 & 11.9 & 2867 & 2.0521 & 40.685 & 6265 \\
\hline & FPS & 0.28 & 10.9 & 5733 & 0.8669 & 21.534 & 7565 \\
\hline
\end{tabular}

ISSN No.: 232 1-3906 (Print) ISSN No.: 2321-7146 (Online) Registration No.: CHAENG/2013/51235 
Table 4: Comparison results of isolator displacement and base shear under different earthquake ground excitations

\begin{tabular}{|c|c|c|c|c|c|}
\hline \multirow{2}{*}{$\begin{array}{c}\text { Earthquake } \\
\text { ground motion }\end{array}$} & \multirow[b]{2}{*}{ Isolator } & \multicolumn{2}{|c|}{$\mathrm{N}=1$} & \multicolumn{2}{|c|}{$\mathrm{N}=\mathbf{5}$} \\
\hline & & $\begin{array}{c}\text { Isolator Dis- } \\
\text { placement }(\mathrm{mm})\end{array}$ & $\begin{array}{c}\text { Base shear } \\
(\mathrm{W})\end{array}$ & $\begin{array}{c}\text { Isolator Dis- } \\
\text { placement }(\mathrm{mm})\end{array}$ & $\begin{array}{c}\text { Base shear } \\
(\mathrm{W})\end{array}$ \\
\hline \multirow{3}{*}{$\begin{array}{c}\text { Imperial } \\
\text { Valley,1979 } \\
\text { El Centro (Array \#5) }\end{array}$} & MVFPS & 245.68 & 0.3971 & 220.43 & 0.3713 \\
\hline & VFPS & 238.71 & 0.3836 & 211.61 & 0.351 \\
\hline & FPS & 283.56 & 0.3352 & 285.62 & 0.3372 \\
\hline \multirow{3}{*}{$\begin{array}{c}\text { Imperial } \\
\text { Valley,1979 } \\
\text { El Centro (Array \#7) }\end{array}$} & MVFPS & 265.23 & 0.4168 & 248.67 & 0.3997 \\
\hline & VFPS & 262.01 & 0.41 & 248.61 & 0.3949 \\
\hline & FPS & 363.44 & 0.4156 & 361.21 & 0.4131 \\
\hline \multirow{3}{*}{$\begin{array}{c}\text { Northridge } \\
1994 \\
\text { (Newhall) }\end{array}$} & MVFPS & 236.99 & 0.3884 & 232.26 & 0.3831 \\
\hline & VFPS & 237.87 & 0.3826 & 233.13 & 0.3771 \\
\hline & FPS & 321.37 & 0.3723 & 303.42 & 0.3552 \\
\hline \multirow{3}{*}{$\begin{array}{c}\text { Landers } \\
1992 \\
\text { (Lucerne Valley) }\end{array}$} & MVFPS & 264.39 & 0.4159 & 137.4 & 0.2882 \\
\hline & VFPS & 258.77 & 0.4063 & 246.06 & 0.392 \\
\hline & FPS & 320.62 & 0.3725 & 305.43 & 0.3572 \\
\hline \multirow{3}{*}{$\begin{array}{c}\text { Northridge } \\
1994 \\
\text { (Rinaldi) }\end{array}$} & MVFPS & 513.7 & 0.651 & 473.22 & 0.626 \\
\hline & VFPS & 513.43 & 0.6531 & 476.88 & 0.6207 \\
\hline & FPS & 573.87 & 0.6273 & 528.34 & 0.5815 \\
\hline \multirow{3}{*}{$\begin{array}{c}\text { Northridge } \\
1994 \\
\text { (Sylmar) }\end{array}$} & MVFPS & 414.32 & 0.5668 & 413.47 & 0.5651 \\
\hline & VFPS & 399.6 & 0.5494 & 387.18 & 0.5831 \\
\hline & FPS & 557.09 & 0.611 & 540.43 & 0.5931 \\
\hline
\end{tabular}

The above Table 3 shows result of Fig 4. to 6 for one storey building and fig 8 to 9 for five storey building with building equipment. From Table 3 it is clearly shows that increasing number of storey equipment acceleration, displacement and recoverable energy also increased.

Table 4 shows result of Fig. 7 and 11 for different earthquake ground excitations. This table depict result of isolator displacement and base shear for one storey and five storey building.

\section{Conclusions}

The Base isolated multi-storied building with light weight equipment at top is analyzed to determine its response under nearfault ground excitations with the help of Newmark's linear acceleration method. One and five storey buildings with equipment system isolated with MVFPS are compared with that of FPS and VFPS. The different response quantities examined are equipment displacement, equipment acceleration and recoverable energy. Following conclusions are derived from this comparative study:

From the above study, it is evident that equipment acceleration and equipment displacement increases when studied for five storey building-equipment system as compare to that of a single storey building-equipment system isolated using MVFPS,VFPS and FPS, where there is little increase observed in recoverable energy for five storey building as compared to that of a single storey building. FPS is performing better in reducing equipment acceleration 
and equipment displacement as compared to VFPS and MVFP.

It is found that in MVFPS, base shear and isolator displacement are less as compared to that of VFPS and FPS. The amount of energy dissipation is higher in case of MVFPS than that of FPS and VFPS. From this study it show that MVFPS is more efficient in reducing recoverable energy than FPS, but less efficient than VFPS.

\section{References}

[1] P. Murnal and R. Sinha, "Aseismic design of structure -equipment systems using variable frequency pendulum isolator", Nuclear Engineering and Design, vol. 231, pp. 129 - 139, 2004.

[2] L. Lu, "Near-fault seismic isolation using sliding bearings with variable curvatures", $13^{\text {th }}$ World Conference on Earthquake Engineering, Canada, 2004

[3] M. Joshi, V. R. Panchal and D. P. Soni, "Aseismic design of building equipment system using conical friction pendulum isolator", International Journal of Emerging Technology and Advanced Engineering, vol. 8, pp. 10-16, 2018.

[4] V. Bhayani and V. R. Panchal, "Seismic response of building-equipment isolated with polynomial friction pendulum isolator", $2^{\text {nd }}$ International Conference on Current Research Trends in Engineering and Technology, Vadodara, 2018.

[5] A. Shaikhzadehi and A. Karamoddin, "Behaviour of sliding isolators with variable friction under near-fault earthquakes", $7^{\text {th }}$ International Conference on Earthquake Engineering and Seismology, Iran, May 2015

[6] P. R. Bhavsar and V. R. Panchal, "Seismic behavior of multi-storied building isolated with modified variable friction pendulum system under harmonic ground motions", International Conference on Technology and Management (ICTM), $17^{\text {th }}-18^{\text {th }}$ February, Visnangar, Gujarat, 2017. 